\title{
PENGEMBANGAN BUKU AJAR BAHASA JEPANG DALAM KEGIATAN EKSTRAKURIKULER BAHASA JEPANG DI SD MUTIARA SINGARAJA
}

\author{
N. K. Juliantini ${ }^{1}$, K. E. K. Adnyani ${ }^{2}$, N. N. Suartini ${ }^{3}$ \\ Program Studi Pendidikan Bahasa Jepang \\ Universitas Pendidikan Ganesha \\ Singaraja, Indonesia \\ e-mail: juliantini.komang@undiksha.ac.id \\ krishna.adnyani@undiksha.ac.id suartini@gmail.com
}

\begin{abstract}
Abstrak
Penelitian ini bertujuan untuk mengembangkan buku ajar bahasa Jepang yang digunakan dalam kegiatan ekstrakurikuler bahasa Jepang di SD Mutiara Singaraja. Penelitian ini merupakan penelitian dan pengembangan yang menggunakan model pengembangan Hannafin dan Peck. Data dikumpulkan dengan observasi, wawancara, angket dan dianalisis secara deskriptif kualitatif. Hasil dari penelitian ini yaitu (1) berdasarkan hasil uji ahli materi dan media pembelajaran, buku ajar ini sangat sesuai, (2) berdasarkan respons guru dan siswa, buku ajar yang dikembangkan sangat sesuai dan layak digunakan. Diharapkan buku ajar yang dikembangkan dapat digunakan dalam kegiatan ekstrakurikuler bahasa Jepang di SD Mutiara Singaraja.
\end{abstract}

Kata Kunci: Pengembangan, Buku ajar bahasa Jepang, Ekstrakurikuler
要旨
本研究の目的は
ムティアラシンガラジャ私立小学校で日本語の課外に必要な教科書を開発するため
である。データは調査、インタビュー、アンケートによって収集し、定性的記述法
により分析し、Hannafin and
Peckモデルを用いた。結果は（1）日本語指導の専門家及びデザインに関する専門家 の検閲において、作成した教科書は適していて、（2）先生と生徒平価、高く評価 された。今後、作成した教科書はムティアラシンガラジャ私立小学校で日本語の課 外の中に使用される。
キーワード：開発する、日本語の教科書、課外

\section{Pendahuluan}

Bahasa Jepang merupakan salah satu bahasa asing yang diajarkan di Indonesia. Berdasarkan survei yang dilakukan oleh The Japan Foundation pada tahun 2015, Indonesia merupakan negara kedua dengan jumlah pembelajar bahasa Jepang paling banyak di dunia (School, 2012). Menurut survei tersebut jumlah pembelajar bahasa Jepang di Indonesia saat ini adalah 745.000 orang, dengan perbandingan jumlah pembelajar tingkat menengah lebih banyak dari pada tingkat atas.

Bahasa Jepang tidak hanya menjadi pelajaran umum, tetapi bahasa Jepang juga dijadikan sebagai kegiatan ekstrakurikuler. Salah satunya adalah SD Mutiara Singaraja.

SD Mutiara Singaraja adalah salah satu sekolah yang menjadikan bahasa Jepang sebagai kegiatan ekstrakurikuler. Berdasarkan wawancara yang dilakukan terhadap guru pembina, awalnya kegiatan ekstrakurikuler bahasa Jepang diadakan karena hanya ingin mencoba. Tetapi setelah mendapatkan respons positif dari siswa, kegiatan ekstrakurikuler bahasa Jepang ditetapkan menjadi salah satu kegiatan ekstrakurikuler di SD Mutiara Singaraja.

Pelaksanaan kegiatan ekstrakurikuler bahasa Jepang dilaksanakan setiap hari Rabu bertempat di SD Mutiara Singaraja. Kegiatan ekstrakurikuler ini dibina oleh pengajar yang memiliki latar pendidikan bahasa Jepang. 
Berdasarkan wawancara yang dilakukan, kegiatan ekstrakurikuler bahasa Jepang di SD Mutiara Singaraja tidak menggunakan buku ajar sebagai pedoman. Hal ini menyebabkan kegiatan ekstrakurikuler bahasa Jepang berjalan tidak efektif. Banyak siswa yang tidak memperhatikan penjelasan guru dan bercanda dengan temannya.

Gregorc (2001) menyatakan bahwa anak lebih mengerti informasi yang disampaikan secara jelas dan nyata, daripada yang abstrak. Hal ini berarti diperlukan sesuatu yang konkret, suatu media yang digunakan dalam pembelajaran, sehingga pembelajaran dapat berjalan efektif. Salah satu media pembelajaran yang dapat digunakan adalah buku ajar.

Buku ajar adalah salah satu media pembelajaran yang dapat dilihat dan diakses secara langsung oleh siswa (Musfiqoon, 2012). Dengan buku ajar, siswa dapat secara langsung melihat dan mengakses materi pembelajaran.

Buku ajar akan memberikan kemudahan, baik bagi siswa maupun guru. Bagi siswa dengan adanya buku ajar, maka siswa akan lebih mudah memahami materi yang diajarkan karena siswa memiliki buku sebagai pegangan. Siswa tidak hanya belajar di sekolah, tetapi dengan adanya buku ajar diharapkan siswa juga belajar di rumah, baik mengulang materi yang telah diajarkan oleh guru maupun menyiapkan materi selanjutnya. Bagi guru keberadaan buku ajar akan memberikan kemudahan dalam proses perencanaan maupun pelaksanaan kegiatan ekstrakurikuler. Dengan demikian proses pembelajaran akan berjalan lebih efektif.

Berdasarkan paparan tersebut, maka diperlukan sebuah buku ajar bahasa Jepang sebagai pedoman dalam mengajar kegiatan ekstrakurikuler di SD Mutiara Singaraja. Tujuannya yaitu untuk memberikan panduan kepada guru dalam mengajar kegiatan ekstrakurikuler, sehingga memudahkan guru dalam menyampaikan materi. Selain itu siswa juga lebih mudah memahami materi jika tersedia buku ajar kegiatan ekstrakurikuler bahasa Jepang untuk anak-anak SD.

Adapun rumusan masalah dari penelitian ini adalah bagaimanakah buku ajar yang digunakan dalam kegiatan ekstrakurikuler bahasa Jepang di SD Mutiara Singaraja.

Berdasarkan rumusan masalah tersebut, tujuan dari penelitian ini yaitu untuk mengembangkan buku ajar bahasa Jepang dalam kegiatan ekstrakurikuler bahasa Jepang di SD Mutiara Singaraja, sehingga memudahkan guru maupun siswa dalam kegiatan ekstrakurikuler bahasa Jepang.

Spesifikasi produk yang akan dikembangkan yaitu (1) buku ajar yang dihasilkan adalah buku yang berbentuk media cetak. Buku yang akan dihasilkan lebih banyak memuat gambar-gambar. (2) Produk yang dihasilkan adalah buku ajar untuk kegiatan ekstrakurikuler bahasa Jepang untuk siswa sekolah dasar. Buku ajar ini memuat materi-materi dasar bahasa Jepang untuk siswa sekolah dasar. (3) Buku ini terdiri dari halaman sampul, kata pengantar, daftar isi, kosakata, pola kalimat, percakapan, latihan-latihan soal, dan lampiran.

Menurut Musfiqoon (2012) buku ajar adalah salah satu media pembelajaran yang dapat dilihat dan diakses secara langsung oleh siswa. Dengan buku ajar, siswa dapat secara langsung melihat dan mengakses materi pembelajaran.

Buku ajar merupakan salah satu komponen penting dalam proses belajar mengajar. Buku ajar memudahkan guru dalam mengajar karena buku ajar sebagai pedoman dalam mengajar, sehingga pembelajaran tersusun secara sistematis. Selain itu, keberadaan buku ajar juga memudahkan siswa dalam memahami materi karena dalam buku ajar siswa dapat memperoleh informasi maupun pengetahuan terkait dengan pembelajaran.

Menurut Prastowo (dalam Imran, 2014), berikut merupakan fungsi, tujuan, dan manfaat buku ajar adalah.

Fungsi buku ajar

1. Sebagai bahan referensi atau bahan rujukan bagi peserta didik

2. Sebagai bahan evaluasi

3. Sebagai alat bantu pendidik dalam melaksanakan kurikulum

4. Sebagai salah satu penentu metode atau teknik pengajaran yang akan digunakan oleh pendidik.

5. Sebagai sarana untuk meningkatkan karir dan jabatan. 
Tujuan buku ajar

1. Memudahkan guru dalam menyampaikan materi pembelajaran

2. Memberi kesempatan kepada siswa untuk mengulangi pelajaran atau mempelajari materi baru yang akan diajarkan

3. Menyediakan materi pembelajaran yang menarik bagi siswa.

Manfaat buku ajar

1. Membantu siswa dalam melaksanakan kurikulum karena disusun berdasarkan kurikulum yang berlaku

2. Menjadi pegangan guru dalam menentukan metode pengajaran

3. Memberi kesempatan bagi siswa untuk mengulangi pelajaran atau mempelajari materi yang baru

4. Memberikan pengetahuan bagi siswa maupun guru

5. Menjadi penambah nilai angka kredit untuk mempermudah kenaikan pangkat atau golongan

6. Menjadi sumber penghasilan jika diterbitkan.

Berdasarkan fungsi, tujuan dan manfaat buku ajar yang telah dipaparkan maka dapat disimpulkan bahwa buku ajar memiliki peran penting dalam pembelajaran. Buku ajar memberikan kemudahan, baik bagi guru maupun siswa.

Pengertian Kegiatan Ekstrakurikuler

Kegiatan ekstrakurikuler adalah salah satu program sekolah yang dilakukan di luar pelajaran sekolah. Artinya tidak berkaitan dengan pembelajaran wajib di kelas. Kegiatan ini adalah salah satu cara sekolah untuk mewadahi minat dan bakat siswa di sekolah.

Menurut Peraturan Menteri Pendidikan Nasionaal Republik Indonesia Nomor 39 Tahun 2008 tentang Pembinaan Kesiswaan (2008: 4), kegiatan ekstrakurikuler adalah salah satu jalur pembinaan kesiswaan. Melalui kegiatan ekstrakurikuler di sekolah, siswa yang memiliki kemampuan akademik maupun non-akademik dapat dibina oleh sekolah sehingga kemampuan siswa berkembang.

Fungsi Kegiatan Ekstrakurikuler

Noor (dalam Budjang, 2013) menyatakan bahwa fungsi kegiatan ekstrakurikuler adalah untuk membantu pengembangan peserta didik dan pemantapan pengembangan kepribadian siswa yang cenderung berkembang untuk memilih jalan tertentu. Dari pengertian tersebut, maka kegiatan ekstrakurikuler berfungsi sebagai sarana penunjang bagi proses pembelajaran yang dilaksanakan di sekolah yang berguna untuk mengaplikasikan teori dan praktik yang telah diperoleh sebagai hasil nyata proses pembelajaran.

Berikut merupakan fungsi kegiatan ekstrakurikuler menurut Panduan Pengembangan Diri Peraturan Menteri Pendidikan Nasional Nomor 22 Tahun 2016 (dalam Rijal, 2016) yaitu:

1. Pengembangan, yaitu fungsi kegiatan ekstrakurikuler untuk mengembangkan kemampuan dan kreativitas siswa sesuai dengan potensi, bakat, dan minat siswa.

2. Sosial, yaitu fungsi kegiatan ekstrakurikuler untuk mengembangkan kemampuan dan rasa tanggung jawab sosial peserta didik.

3. Rekreatif, yaitu fungsi kegiatan ekstrakurikuler untuk mengembangkan suasana rileks, meggembirakan dan menyenangkan bagi peserta didik yang menunjang proses perkembangan.

4. Persiapan karir, yaitu fungsi kegiatan ekstrakurikuler untuk mengembangkan kesiapan karir peserta didik.

Dengan demikian, kegiatan ekstrakurikuler memiliki fungsi penting di sekolah. Kegiatan ekstrakurikuler dapat menjadi wadah minat dan bakat siswa.

\section{Metode}

Model Penelitian dan Pengembangan

Dalam penelitian dan pengembangan, terdapat beberapa model yang dapat digunakan. Dalam penelitian ini, digunakan model penelitian dan pengembangan Hannafin dan Peck. Alasan penggunaan model penelitian dan pengembangan ini karena model 
Hannafin dan Peck hanya terdiri dari 3 langkah, tetapi sudah mencakup semua fase yang diperlukan dalam penyusunan suatu buku ajar. Model penelitian ini terdiri dari tiga tahap (Tegeh, 2014:1) yaitu.

1. Analisis kebutuhan

Pada tahap ini hal yang dilakukan adalah menganalisis kebutuhan-kebutuhan dalam mengembangkan suatu media pembelajaran termasuk di dalamnya terdapat tujuan, media pembelajaran yang diperlukan, pengetahuan, keterampilan, serta peralatan yang diperlukan oleh kelompok sasaran. Untuk mengetahui kebutuhan ataupun permasalahan yang dihadapi, dilakukan wawancara terhadap guru pembina kegiatan ekstrakurikuler dan observasi kegiatan ekstrakurikuler.

Pada tahap analisis kebutuhan, dilakukan wawancara terhadap guru pembina kegiatan ekstrakurikuler dan observasi terhadap guru dan siswa dalam kegiatan ekstrakurikuler. Kegiatan ini bertujuan untuk memperoleh informasi mengenai kegiatan ekstrakurikuler di SD Mutiara Singaraja dan permasalahan yang dihadapi selama kegiatan ekstrakurikuler.

Berdasarkan wawancara dan observasi yang telah dilakukan, ditemukan beberapa permasalahan dalam kegiatan ekstrakurikuler. Salah satu permasalahan yang ditemukan adalah tidak tersedianya buku ajar dalam kegiatan ekstrakurikuler bahasa Jepang di SD Mutiara Singaraja. Berdasarkan wawancara yang telah dilakukan, kegiatan ekstrakurikuler tanpa buku menyebabkan kesulitan, baik bagi guru maupun siswa. Guru sedikit kesulitan dalam menentukan materi yang diberikan karena tidak ada pedoman dalam mengajar.. Sedangkan bagi siswa, tidak tersedianya buku ajar menyebabkan kesulitan dalam memahami materi, apalagi bahasa yang dipelajari merupakan bahasa asing. Oleh sebab itu, keberadaan buku ajar menjadi sangat penting.

$2 . \quad$ Perancangan (design)

Pada tahap ini informasi dari analisis kebutuhan dipindahkan ke dalam bentuk dokumen yang akan menjadi tujuan pembuatan suatu produk. Setelah dilakukannya wawancara dan observasi pada tahap analisis kebutuhan, selanjutnya hasil wawancara dan observasi dianalisis dan ditarik kesimpulan sehingga mendapatkan suatu solusi dari permasalahan yang ditemukan dari analisis kebutuhan.

Pada tahap ini ditentukan produk yang akan dibuat dan bagaimana rancangan dari produk yang akan dibuat. Pada penelitian ini, produk yang akan dibuat adalah buku ajar yang terdiri dari 10 bab. Dalam buku ajar akan dilengkapi dengan gambar-gambar agar menarik, sehingga mudah dipahami oleh siswa. Dalam buku ajar ini akan dilengkapi dengan lagu-lagu pada beberapa bab.

3. Pengembangan dan implementasi

Hal yang dilakukan pada tahap ini adalah penghasilan diagram alur dan pengujian. Dalam pembuatan diagaram alur menggunakan dokumen story board sebagai landasan untuk membantu proses pembuatan produk. Sedangkan pengujian bertujuan untuk mengetahui kelayakan produk yang dikembangkan dalam kegiatan ekstrakurikuler bahasa Jepang.

Pada tahap ini, setelah buku ajar selesai dilakukan uji ahli oleh ahli dan uji coba produk oleh kelompok sasaran. Uji ahli bertujuan untuk mengetahui kelayakan buku ajar yang dikembangkan, sedangkan uji coba produk bertujuan untuk mengetahui respons kelompok sasaran terhadap buku ajar yang dikembangkan.

Uji Coba Produk

Penelitian ini merupakan jenis penelitian dan pengembangan. Berdasarkan beberapa pengertian dari ahli, penelitian dan pengembangan ini merupakan salah satu penelitian yang menghasilkan dan menyempurnakan suatu produk.

Pada penelitian ini sebelum suatu produk layak atau tidak digunakan, terlebih dahulu dilakukan uji coba produk oleh ahli ataupun pengguna produk. Instrumen yang digunakan berupa angket uji ahli produk. Dalam angket terdapat beberapa pernyataan terkait isi/materi buku ajar dan media pembelajaran.

Jenis Data 
Jenis data yang digunakan dalam penelitian ini adalah data kualitatif. Data kualitatif didapat dari hasil wawancara, observasi, saran, pendapat, dan komentar dari validator. Selain dari validator, data kualitatif didapat dari hasil angket yang diisi oleh guru pembina dan peserta kegiatan esktrakurikuler bahasa Jepang di SD Mutiara Singaraja.

\section{Subjek Uji Coba}

Dalam penelitian dan pengembangan ini, yang menjadi subjek uji coba adalah guru pembina dan siswa yang ikut dalam kegiatan ekstrakurikuler bahasa Jepang di SD Mutiara Singaraja. Tetapi karena jumlah peserta kegiatan ekstrakurikuler bahasa Jepang banyak, maka uji coba produk akan dilakukan hanya ke beberapa anak, 5-6 anak.

Metode dan Instrumen Pengumpulan Data

Dalam pengumpulan data digunakan metode wawancara, observasi dan angket. Berikut penjelasan mengenai metode pengumpulan data.

Metode wawancara digunakan untuk mengetahui permasalahan yang dihadapi dalam kegiatan ekstrakurikuler bahasa Jepang di SD Mutiara Singaraja. Jenis wawancara yang digunakan dalam penelitian ini yaitu wawancara semi terstruktur. Dalam wawancara digunakan instrumen pengumpulan data berupa pedoman wawancara.

Pedoman wawancara memuat beberapa pertanyaan mengenai pelaksanaan dan permasalahan dalam kegiatan ekstrakurikuler bahasa Jepang di SD Mutiara Singaraja.

Metode pengumpulan data yang kedua adalah observasi. Observasi adalah kegiatan mengamati. Dalam penelitian ini observasi dilakukan untuk mngonfirmasi informasi yang didapat dari wawancara.

Metode pengumpulan data yang ketiga adalah angket. Angket digunakan untuk memperoleh penilaian dari uji ahli materi, media pembelajaran, uji coba produk guru pembina dan siswa.

Angket menggunakan lembar angket sebagai instrumen pengumpulan data. Dalam angket memuat beberapa pernyataan mengenai buku ajar yang telah dikembangkan.

\section{Metode dan Teknik Analisis Data}

Data yang diperoleh melalui wawancara, observasi, masukan, saran, komentar dari guru maupun validator, selanjutnya dianalisis menggunakan pendekatan deskriptif kualitatif.

\section{Hasil dan Pembahasan}

Dalam pengembangan buku ajar ini menggunakan model pengembangan Hannafin and Peck. Model pengembangan Hannafin and Peck terdiri dari tiga fase, yaitu fase analisis kebutuhan, fase perancangan, dan fase pengembangan dan implementasi.

Fase 1 (Analisis Kebutuhan)

Pada tahap ini dilakukan wawancara dan observasi. Wawancara dilakukan terhadap guru kegiatan ekstrakurikuler, sedangkan observasi dilakukan terhadap proses kegiatan ekstrakurikuler yang dilaksanakan di SD Mutiara Singaraja. Berdasarkan hasil wawancara ditemukan beberapa permasalahan dalam kegiatan ekstrakurikuler, salah satunya adalah tidak adanya buku ajar dalam kegiatan ekstrakurikuler sehingga hal ini menyebabkan kesulitan, baik bagi guru maupun siswa.

$\mathrm{Hal}$ ini dapat dilihat dari observasi yang telah dilakukan, bahwa kegiatan ekstrakurikuler tidak efektif karena tidak menggunakan buku panduan berupa buku ajar. Banyak siswa yang tidak memperhatikan penjelasan guru karena guru hanya menggunakan metode ceramah.

Oleh sebab itu diperlukannya buku ajar untuk membantu proses pembelajaran dalam kegiatan ekstrakurikuler bahasa Jepang di SD Mutiara Singaraja, sehingga memudahkan guru maupun siswa dalam kegiatan ekstrakurikuler bahasa Jepang di SD Mutiara Singaraja.

Fase 2 (Fase Perancangan)

Pada tahap ini hal yang dilakukan adalah mulai merancang produk yang akan dibuat, seperti pemilihan bentuk media yang akan dikembangkan, pemilihan kosakata dan rancangan awal dari buku ajar yang akan dibuat. 
Buku ajar yang dibuat merupakan buku ajar bahasa Jepang untuk kegiatan ekstrakurikuler bahasa Jepang. Buku ajar teridir dari 10 bab dan tiap bab terdiri dari tema, indikator, kosakata, pola kalimat, percakapan, latihan soal, dan beberapa nyanyian dalam beberapa tema. Pada akhir buku dilengkapi dengan lampiran kosakata, seperti kosakata nama-nama hewan, warna dan buah-buahan.

Fase 3 (Pengembangan dan Implementasi)

Pada tahap ini hal yang dilakukan adalah pengembangan produk. Setelah tahap perancangan produk, dilanjutkan dengan mengembangkan produk yang akan dibuat.

Adapun produk yang dibuat adalah berupa buku ajar bahasa Jepang yang terdiri dari 10 bab. Buku ajar bahasa Jepang yang dibuat disesuaikan dengan materi bahasa Jepang yang diajarkan di SD Mutiara Singaraja. Setelah tahap pengembangan selesai, selanjutnya adalah tahap implementasi.

Pada tahap implementasi ini, hal yang dilakukan adalah mengujicobakan penggunaan buku ajar bahasa Jepang yang telah dibuat terhadap guru pembina dan siswa yang mengikuti kegiatan ekstrakurikuler bahasa Jepang di SD Mutiara Singaraja. Tetapi tahap ini hanya dilakukan pada kelompok kecil karena keterbatasan waktu dan biaya.

Hasil Analisis Data

Buku ajar yang dihasilkan telah melalui beberapa tahapan perbaikan isi materi dan media pembelajaran agar layak digunakan. Tahap uji ahli dilakukan oleh dua orang uji ahli. Uji ahli materi dilakukan oleh dosen bahasa Jepang dan uji media pembelajaran dilakukan oleh dosen DKV (Desain Komunikasi Visual) di Universitas Pendidikan Ganesha.

Tahap uji ahli dilakukan dengan memberikan angket yang berisi beberapa pernyataan mengenai buku ajar kepada para ahli agar dapat dinilai isi materi dan media pembelajarannya. Berikut merupakan hasil uji ahli materi dan media pembelajaran.

Kelayakan Isi

Aspek penilaian yang pertama adalah kelayakan isi. Aspek ini meliputi penyajian materi, judul buku dan indikator. Berdasarkan penilaian dari ahli materi, aspek ini dianggap sangat sesuai.

Penyajian materi sudah sangat sesuai dengan kelompok sasaran, judul buku sangat sesuai dengan isi buku, tugas dan latihan soal sudah disesuaikan dengan indikator. Secara keseluruhan aspek kelayakan ini sudah sangat sesuai.

Kelayakan Penyajian

Aspek penilaian selanjutnya adalah kelayakan penyajian. Aspek ini terdiri dari sistematika penulisan, format buku dan penyajian materi.

Aspek kelayakan penyajian dinilai sudah sangat sesuai. Sistematika penulisan dinilai sangat sesuai dan tepat. Format buku sangat sesuai karena disusun dengan format yang sama pada setiap bab. Penyajian materi dinilai sangat sesuai karena disajikan secara berjenjang (mudah ke sulit).

\section{Penggunaan Bahasa}

Aspek penggunaan bahasa terdiri dari penggunaan bahasa Indonesia, kosakata dan pola kalimat. Berdasarkan penilaian dari ahli materi aspek ini sudah sangat sesuai.

Penggunaan bahasa Indonesia efektif dan mudah dipahami. Kosakata dan pola kalimat yang digunakan sesuai dengan judul bab. Penggunaan kosakata dinilai sangat sesuai karena sederhana dan mudah dipahami.

Kesesuaian Konten Buku

Aspek ini terdiri dari kesesuaian buku ajar dengan sasaran, ukuran buku, isi buku, dan tampilan buku. Berdasarkan penilaian dari ahli media pembelajaran, secara umum aspek ini sudah sesuai. 
Buku ajar yang dikembangkan sudah sesuai dengan sasaran. Ukuran buku sudah sesuai karena ukuran buku praktis dan mudah dibawa. Dilihat dari isi buku ajar, dinilai sudah sesuai karena isi buku mudah dipahami. Dari tampilan buku, dianggap cukup sesuai.

Terdapat komentar dari ahli media pembelajaran mengenai penggunaan huruf. Penggunaan huruf (ukuran dan jenis huruf) dinilai sudah sesuai dan mudah dibaca.

Gambar

Aspek gambar terdiri dari gambar yang digunakan, kesesuaian gambar dengan makna, ukuran gambar, dan tampilan gambar. Secara umum aspek ini dianggap sudah sesuai.

Gambar yang digunakan dalam buku ajar mudah dipahami. Gambar dinilai sudah sesuai dengan makna yang dimaksud. Dilihat dari ukuran gambar, gambar yang digunakan dalam buku ajar sudah sesuai. Dari tampilan gambar, gambar yang digunakan dalam buku ajar menarik. Gambar yang digunakan dinilai sudah sesuai dengan konteks.

Desain Buku

Aspek desain buku terdiri dari desain sampul, tampilan sampul, penulisan judul dan deskripsi buku, kerangka buku sistematis, penggunaan spasi, penggunaan jenis dan ukuran huruf. Secara umum aspek ini dinilai sudah sesuai.

Desain sampul buku dinilai sudah sesuai dengan judul buku. Tampilan sampul dinilai sudah menarik. Penulisan judul, penulis dan deskripsi buku dinilai jelas dan mudah dipahami. Terdapat masukan pada bagian penulisan judul buku yaitu jenis huruf yang digunakan pada judul buku agar lebih akurat.

Dari kerangka buku dinilai sudah sistematis, karena setiap bab disusun dengan sistematis yang sama yaitu judul bab, indikator, kosakat baru, pola kalimat, percakapan, dan latihan soal.

Berdasarkan penilaian dari ahli materi dan media pembelajaran, buku ajar yang dikembangkan dinilai sudah sangat sesuai dan layak digunakan.

Selain dilakukan uji ahli, dilakukan juga uji coba produk terhadap guru pembina dan siswa. Hal ini bertujuan untuk mengetahui respons guru pembina dan siswa terhadap buku ajar yang dikembangkan.

Uji coba produk dilakukan dengan cara memberikan guru pembina dan siswa angket yang berisi beberapa pernyataan mengenai buku ajar yang sudah dikembangkan.

Berdasarkan penilaian dari guru pembina dan siswa, buku ajar yang dikembangkan dianggap sangat sesuai dan layak digunakan dalam kegiatan ekstrakurikuler bahasa Jepang di SD Mutiara Singaraja. Dari materi maupun media pembelajarannya, buku ajar yang dikembangkan dinilai sudah sangat sesuai.

Revisi Produk

Revisi produk dilakukan berdasarkan validasi atau penilaian yang diberikan oleh ahli melalui angket. Revisi juga dilakukan berdasarkan saran atau masukan dari dosen pembimbing dan guru. Revisi dilakukan untuk mendapatkan media yang baik dan layak.

Dalam penelitian ini ada beberapa hal yang direvisi.

1. Judul buku. Judul buku yang digunakan sebelumnya dinilai terlalu umum, sehingga diberi masukan agar menggunakan judul buku yang lebih khusus sesuai dengan kelompok sasaran.

2. Cover. Dalam buku ajar ini, cover yang digunakan dinilai tidak sesuai. Tata letak dari bagian cover juga tidak sesuai, sehingga diberi masukan agar menggunakan cover yang lebih menarik dan sesuai.

3. Beberapa gambar. Berdasarkan masukan dari validator beberapa gambar dinilai tidak jelas, sehingga perlu dilakukan revisi. Selain itu, diberikan masukan untuk menggunakan anak kecil sebagai model gambar karena kelompok sasaran dari buku ajar ini yaitu anak-anak sekolah dasar.

Secara umum dapat disimpulkan bahwa hal yang lebih banyak direvisi adalah gambargambar yang digunakan dalam buku ajar. 


\section{Pembahasan}

Berdasarkan hasil wawancara dan observasi yang dilakukan, diketahui bahwa dalam kegiatan ekstrakurikuler bahasa Jepang di SD Mutiara Singaraja mengalami beberapa kesulitan, salah satunya adalah tidak terdapat buku ajar yang dijadikan sebagai pedoman dalam kegiatan ekstrakurikuler bahasa Jepang.

Buku ajar memiliki peran penting dalam pembelajaran karena dijadikan sebagai referensi atau pedoman oleh guru maupun siswa. Hal ini sejalan dengan pendapat Prastowo (dalam Rahman, 2018: 47) yang menyatakan bahwa salah satu fungsi buku ajar adalah sebagai referensi untuk siswa. Oleh sebab itu keberadaan buku ajar sebagai pedoman dalam kegiatan ekstrakurikuler bahasa Jepang di SD Mutiara Singaraja diperlukan.

Berdasarkan faktor tersebut, maka dikembangkan buku ajar sebagai pedoman dalam mengajar untuk memudahkan guru maupun siswa dalam kegiatan ekstrakurikuler. Dengan adanya buku ajar, maka kegiatan ekstrakurikuler menjadi lebih efektif.

Pengembangan buku ajar ini dilakukan dengan menggunakan model penelitian Hannafin dan Peck yang terdiri dari tiga tahap yaitu analisis kebutuhan, perancangan dan pengembangan dan implementasi (Tegeh, 2014:1).

Pada tahap analisis kebutuhan dilakukan wawancara dan observasi untuk mengetahui informasi awal mengenai kegiatan ekstrakurikuler bahasa Jepang di SD Mutiara Singaraja. Wawancara dilakukan dengan cara mengajukan beberapa pertanyaan kepada guru pembina, sedangkan observasi dilakukan dengan cara mengamati secara langsung proses berjalannya kegiatan ekstrakurikuler bahasa Jepang di SD Mutiara Singaraja.

Setelah diadakan wawancara dilanjutkan dengan observasi. Observasi bertujuan untuk mengonfirmasi informasi yang didapat dari wawancara. Dari wawancara dan observasi, ditemukan beberapa permasalahan dalam kegiatan ekstrakurikuler bahasa Jepang di SD Mutiara Singaraja, salah satunya adalah tidak ada buku ajar yang dijadikan sebagai pedoman dalam kegiatan ekstrakurikuler bahasa Jepang di SD Mutiara Singaraja.

Tahap kedua adalah perancangan. Setelah analisis kebutuhan, dilanjutkan dengan perancangan. Pada tahap perancangan ini mulai ditentukan bentuk media pembelajaran yang akan dikembangkan, kosakata yang akan digunakan dan rancangan buku secara umum.

Dalam penelitian ini, produk yang dikembangkan adalah buku ajar. Buku ajar terdiri dari 10 bab dan buku ajar ditulis dengan Romaji.

Tahap ketiga adalah pengembangan dan implementasi. Pada tahap ini rancangan produk dikembangkan, sehingga menjadi produk yang sesuai dengan tujuan. Setelah tahap perancangan, dilanjutkan dengan implementasi.

Sebelum tahap implementasi dilakukan uji ahli materi dan media pembelajaran untuk mengetahui kelayakan buku ajar yang dikembangkan. Uji ahli materi dilakukan oleh dosen program pendidikan bahasa Jepang dan dosen Desain Komunikasi Visual.

Setelah dilakukan uji ahli dan diperbaiki sesuai dengan masukan dari validator, diadakan uji coba produk terhadap guru pembina dan siswa. Hal ini bertujuan untuk mengetahui respons guru pembina dan siswa mengenai buku ajar yang dikembangkan.

Berdasarkan penilaian uji ahli, secara umum buku ajar yang dikembangkan sudah sangat sesuai dan layak digunakan, sedangkan berdasarkan penilaian guru pembina dan siswa, buku ajar yang dikembangkan sudah sangat sesuai.

\section{Simpulan dan Saran}

Simpulan dari pengembangan buku ajar bahasa Jepang adalah sebagai berikut.

Buku ajar yang dikembangkan adalah buku ajar bahasa Jepang untuk kegiata ekstrakurikuler bahasa Jepang di SD Mutiara Singaraja. Buku ajar yang dikembangkan menggunakan model pengembangan Hannafin dan Peck yang terdiri dari tiga tahap, yaitu tahap analisis kebutuhan, perancangan, dan pengembangan dan implementasi.

Buku ajar yang dikembangkan terdiri dari 10 bab dan ditulis dengan Romaji. Setiap bab disusun dengan sistematika yang sama yaitu judul bab, indikator, kosakata baru, pola kalimat, latihan percakapan, dan latihan soal. Dalam beberapa bab dilengkapi dengan 
nyanyian-nyanyian yang disesuaikan dengan materi yang dipelajari. Buku ajar yang dikembangkan juga dilengkapi dengan lampiran kosakata pada halaman terakhir buku.

Sebelum menghasilkan buku ajar yang layak digunakan, dilakukan uji ahli materi dan media pembelajaran. Setelah diadakan uji ahli, dilakukan revisi dan uji coba produk terhadap guru pembina dan siswa. Hal ini bertujuan untuk mengetahui respons guru pembina dan siswa mengenai buku ajar yang dikembangkan.

Berdasarkan uji ahli dan uji coba produk, buku ajar yang dikembangkan dinyatakan layak untuk digunakan.

Berdasarkan simpulan, berikut merupakan hal yang dapat disarankan.

1.Bagi guru pembina dan siswa, dengan adanya buku ajar bahasa Jepang ini, diharapkan dapat membantu kegiatan ekstrakurikuler bahasa Jepang di SD Mutiara Singaraja. Buku ajar ini dapat dijadikan sebagai buku pedoman dalam mengajar bahasa Jepang oleh guru pembina kegiatan ekstrakurikuler bahasa Jepang di SD Mutiara Singaraja.

2.Bagi mahasiswa/peneliti lain, diharapkan dapat mengembangkan buku ajar bahasa Jepang untuk siswa sekolah dasar yang memuat lebih banyak nyanyian-nyanyian karena dalam buku ajar ini hanya memuat dua nyanyian.

\section{Daftar Pustaka}

Budjang, dkk. 2013. Fungsi Kegiatan Ekstrakurikuler dalam Meningkatkan Integrasi Sosial Siswa SMA Negeri 1 Segedong. Dalam jurnal.untan.ac.id.

Gregorc. 2001. "Gaya Belajar Menurut Gregorc". Dalam http://m.pepak.sabda.org/03/oct/20 01/anak_gaya_belajar_menurut_G regorc. Diunduh tanggal 17 Agustus 2017.

Imran, Syaiful. 2014. "Fungsi dan Manfaat Penggunaan Buku Teks Pelajaran dalam Pembelajaran."Dalam http://ilmu- pendidikan.net/pustaka/buku/

fungsi- tujuan-dan- manfaat- penggunaan-buku-teks-pelajaran-

dalam-pembelajaran. Diunduh tanggal 18 Juni 2017.

Musfiqoon. 2012. Pengembangan Media dan Sumber Media Pembelajaran.

Jakarta: PT Prestasi Pustakaraya.

Peraturan Menteri Pendidikan Nasionaal Republik Indonesia Nomor 39 Tahun 2008 tentang Pembinaan Kesiswaan.

Rijal. 2016. "Fungsi dan Prinsip Kegiatan Ekstrakurikuler".

Dalam https://www.rijal.com. Diunduh tanggal 18 Juni 2017.

School, Mayantara. 2012. "Survei Lembaga Pendidikan Jepang di Indonesia Tahun 2012". Dalam http://mayantara.sch.id/artikel/surv ei-lembaga-pendidikan-bahasajepang -di-indonesia-tahun- 2012.htm. Diunduh 18 Juni 2017.

Tegeh, Made. 2014. Model Penelitian dan Pengembangan. Yogyakarta:

Graha IImu. 